\title{
Estudio cinético de la adsorción de iones metálicos de aguas residuales en sub-productos de la industria del carbón
}

INGENIERÍA AMBIENTAL

\section{Kinetic study of metal ion adsorption from wastewater onto coal industry by-products}

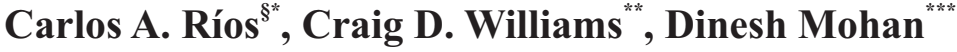 \\ *Escuela de Geología, Universidad Industrial de Santander, Bucaramanga, Colombia, \\ scarios@uis.edu.co \\ ** School of Applied Sciences, University of Wolverhampton, England, \\ c.williams@wlv.ac.uk \\ ***Environmental Sciences, School of Environmental Sciences, Jawaharlal Nehru University, India, \\ dmohan@mail.jnu.ac.in
}

(Recibido: Septiembre 9 de 2010- Aceptado: 27 de 2011)

\begin{abstract}
Resumen
Se llevó a cabo un estudio comparativo sobre el uso de cenizas volantes y clinker natural como adsorbentes de metales pesados de agua contaminada a partir de experimentos de adsorción a temperatura ambiente. Las concentraciones de metales pesados en los filtrados se determinaron por espectrometría de emisión atómica por plasma inductivamente acoplado. En los estudios de adsorción en batch, la retención aumento con el aumento del tiempo de contacto, la cantidad de adsorbente y el $\mathrm{pH}$ de la solución. La adsorción de los metales a partir de la solución contaminada artificialmente fue $\mathrm{Cr}>\mathrm{Cu}>\mathrm{Pb}>\mathrm{Ni}>\mathrm{Zn}$, mientras que a partir de drenaje ácido de mina fue $\mathrm{Pb}>\mathrm{Zn}>\mathrm{As}>\mathrm{Fe}>\mathrm{Cr}>\mathrm{Cu}>\mathrm{Ni}$. Las constantes de primer orden de Lagergren se calcularon para concentraciones iniciales de iones metálicos específicas, dando un excelente ajuste como lo indica el coeficiente de correlación $\left(\mathrm{R}^{2}\right)$, con valores próximos o iguales a 1 para el tratamiento de la solución contaminada artificialmente y de 0.25 a 0.99 para el tratamiento del drenaje ácido de mina. Los datos de este estudio revelan que los cationes metálicos en solución acuosa pueden ser adsorbidos exitosamente en cantidades significativas por los adsorbentes usados.
\end{abstract}

Palabras Claves: Cenizas volantes, Clinker natural, Agua contaminada, Metales pesados, Adsorción.

\begin{abstract}
A comparative study on the use of fly ash (FA) and natural clinker (NC) as heavy metal adsorbents from polluted water was carried out using adsorption experiments at room temperature. The concentrations of heavy metals in the filtrates were determined by inductively coupled plasma-atomic emission (ICP-AE) spectrometry. In batch mode adsorption studies, removal increased with an increase of contact time, adsorbent amount and solution $\mathrm{pH}$. Adsorption of metals from artifitially poluted sulution (APS) was $\mathrm{Cr}>\mathrm{Cu}>\mathrm{Pb}>\mathrm{Ni}>\mathrm{Zn}$, whereas from acid mine drainage (AMD) was $\mathrm{Pb}>\mathrm{Zn}>\mathrm{As}>\mathrm{Fe}>\mathrm{Cr}>\mathrm{Cu}>\mathrm{Ni}$. The Lagergren's first-order rate constants were calculated for specific initial concentrations of metal ions, giving an excellent fit as indicated by the correlation coefficient $\left(\mathrm{R}^{2}\right)$, with values close or equal to 1 for treated APS and from 0.25 to 0.99 for treated AMD. Data from this study reveal that metal cations from aqueous solution can be adsorbed successfully in significant amounts by the used adsorbents.
\end{abstract}

Keywords: Fly ash; Natural clinker; Polluted water; Heavy metals; Adsorption 


\section{Introduction}

The major sources of wastewater can be classified as municipal, industrial, and agricultural. Different types of polluted aqueous effluents may be produced as a result of mining, containing relatively high levels of heavy metals. AMD is a serious environmental problem associated to the mining industry that result from the oxidation of complex sulphides by atmospheric oxygen and bacteria thus originating the formation of sulphuric acid and the dissolution of iron and heavy metals. Although AMD is naturally occurring, mining activities may greatly accelerate its production because open pit and underground mine walls, overburden and mine waste piles exposes fresh iron and sulphide surfaces to oxygen. Predictions of the future loading of dissolved metals from inactive mine sites suggest that sulfide oxidation and the release of dissolved metals will continue for decades to centuries (Dubrovsky et ál., 1985). Estimated costs for stabilization of these sites are in the billions of dollars (Feasby et ál., 1991). AMD is characterized by a low $\mathrm{pH}$-value and high levels of sulfate and metals (Mohan and Chander, 2000), resulting from the weathering of sulfide minerals, such as pyrite $\left(\mathrm{FeS}_{2}\right)$ to release dissolved $\mathrm{Fe}^{2+}$, $\mathrm{SO}_{4}^{2-}$ and $\mathrm{H}^{+}$, followed by the further oxidation of $\mathrm{Fe}^{2+}$ to $\mathrm{Fe}^{3+}$ and the precipitation of iron as a hydroxide or similar substances, producing more $\mathrm{H}^{+}$. AMD typically contains high concentration of dissolved iron which may exists either in the reduced form $\left(\mathrm{Fe}^{2+}\right)$ or in the oxidized form $\left(\mathrm{Fe}^{3+}\right)$, and its acidity is comprised of hydrogen ion acidity and mineral acidity (iron, aluminum, manganese and other metal ions depending on the specific geologic setting and metal sulfide). In the United Kingdom, discharges of AMD from abandoned mines contain a variety of heavy metals that adversely affect different hydrographic basins and are exempt from regulatory control.

The most widely used technique of treatment of AMD for the removal of heavy metals consists in the neutralization with limestone $\left(\mathrm{CaCO}_{3}\right)$ or similar materials, resulting in the precipitation of $\mathrm{Fe}$ and $\mathrm{Mn}$ and other metal hydroxides and also gypsum $\left(\mathrm{CaSO}_{4}\right)$. Treatment of AMD with limestone can increase the $\mathrm{pH}$ to 6.0-7.5 (Pearson and McDonnell, 1975), allowing the metals to be removed from solution. A number of methods for the removal of heavy metals from AMD have been investigated (Webster et ál., 1998; Feng et ál., 2000; Chartrand and Bunce, 2003; Santos et ál., 2004; Gibert et ál., 2005; Wei et ál., 2005; Kalin et ál., 2006), although adsorption has been the preferred method for heavy metal removal, because it is considered to be a particularly effective technique. However, in general these methods are unsustainable in developing countries due to high capital and operating costs. Chemicals can effectively remove certain toxic substances from polluted media but it is presumed to be costly. Therefore, future work should consider experimental investigation of water treatment technology without chemicals, when AMD is treated with natural adsorbents. Numerous types of adsorbents such as organic and inorganic materials have been tested for their ability to remove heavy metals. Water researchers are seeking cheaper raw materials low-cost sorbents such as zeolites and clay minerals with application in sorption of heavy metals from polluted effluents. Such adsorbents would be a viable replacement or supplement to chemicals, although they should be readily available, economically feasible, and should be regenerated with ease.

Globally, coal industry worldwide produces millions of metric tons per year of coal combustion wastes, which include fly ash, bottom ash, boiler slag, flue gas desulfurization sludge and low-volume wastes, including runoff from coal reserve piles and liquid wastes that are formed during cleaning and routine operations. In general, these wastes are used beneficially in small portions as solid wastes in landfilled, although their disposal poses major challenges and serious environmental problems.

On the other hand, spontaneous combustion of coal seams is a natural phenomenon that has occurred in carboniferous basins. Coal geologists refer as natural clinker to thermally altered sedimentary rocks associated with naturally burned coal seams during the recent geologic past (since early Pliocene time), which are common geologic features that have been reported 
throughout the world (De Boer et ál., 2001), covering extensive areas of carboniferous basins, where down cutting of streams exposed coal seams and enhanced the possibility of spontaneous combustion, a natural phenomenon that can occur at any site where deformation, uplift and dissection have exposed coal to the air (Zhang et ál., 2004). However, the degree of thermal alteration produced by burning coal beds is variable, and a single outcrop may contain altered rocks ranging from slightly baked to entirely fused (Cosca et ál., 1989). The use of zeolites in environmental remediation is restricted due to procurement problem and prohibitive cost, which can be sorted by using low-cost raw materials like FA and NC. The purpose of this study was to evaluate the use of these coal by-products in the purification of polluted effluents, comparing the results obtained with model solutions with those obtained with AMD to establish differences in the removal efficiency.

\section{Experimental methods and materials}

\subsection{Starting materials}

FA was supplied by the Rugeley Power Station, West Midlands (England), being generated by pulverized coal combustion and classified as Class F FA, which is produced from burning anthracite and bituminous coals. NC was collected in an open pit of the Cerrejón coal mining site, situated in the Guajira department (Colombia). The raw materials were prepared by grinding with a SpectroMill Ball Pestle Impact grinder and sieved on 200 mesh and then ground and particles of $<$ $150 \mu \mathrm{m}$ selected for sorption experiments. Nitrate salts like $\mathrm{Cu}\left(\mathrm{NO}_{3}\right)_{2} \cdot 3 \mathrm{H}_{2} \mathrm{O}(99.0 \%$ purity, SigmaAldrich), $\mathrm{Pb}\left(\mathrm{NO}_{3}\right)_{2}$ (analytical grade, Aldrich Chemical Co.), $\mathrm{Zn}\left(\mathrm{NO}_{3}\right)_{2} \cdot 6 \mathrm{H}_{2} \mathrm{O}$ (98.0\% purity, Sigma-Aldrich), $\mathrm{Cr}\left(\mathrm{NO}_{3}\right)_{3} .9 \mathrm{H}_{2} \mathrm{O}(97.0 \%$ purity, Fluka) and $\mathrm{Ni}\left(\mathrm{NO}_{3}\right)_{2} \cdot 6 \mathrm{H}_{2} \mathrm{O}$ (analytical grade, Aldrich Chemical Co.) of the required metals were used to formulate the APS. The correct weight of the nitrate salts and other compounds, such as $\mathrm{CH}_{3} \mathrm{COOH}$ (99.5\% purity, Aldrich Chemical Co.), $\mathrm{C}_{6} \mathrm{H}_{12} \mathrm{O}_{6}$ (analytical grade, Sigma-Aldrich), $\mathrm{CaCl}_{2}$ (95.0\% purity, Merck), $\mathrm{KCl}$ (99.9\% purity, Aldrich Chemical Co.), $\mathrm{NH}_{4} \mathrm{Cl}$ (analytical grade, Aldrich Chemical Co.), $\mathrm{KH}_{2} \mathrm{PO}_{4}$ (99.9\% purity,
Aldrich Chemical Co.), $\mathrm{MgSO}_{4}$ (99.0\% purity, Fisher), were then weighed out and dissolved in distilled water to formulate the artificially polluted stock solutions $(1000 \mathrm{mg} / \mathrm{l})$ containing the selected metals. AMD used in this study was collected from a deep transient pond from rainfall between spoil heaps by the entry road of the Parys Mountain copper-lead-zinc deposit of Anglesey (North Wales), which is strongly acidic $(\mathrm{pH}<2)$ and metal-rich due to the oxidation of sulphide minerals, and its orange-brown colour is due to the very high concentrations of ferric iron in solution.

\subsection{Adsorption experiments and water analyses}

Batch sorption tests were carried out at room temperature using $\mathrm{FA}$ and $\mathrm{NC}$ as sorbents. Dosages of 0.25 or $0.5 \mathrm{~g}$ of sorbent were mixed with $20 \mathrm{ml}$ of APS or AMD in PVC plastic containers by continuous mechanical shaking at a speed of $150 \mathrm{rpm}$ and different contact time intervals $(5,19,30,45,60,120,180,240$ and 300 minutes for APS, and 5, 19, 30, 45, 60, 120, 180, 240 and 1440 minutes for AMD) to explore their ability to remove heavy metals. The mixtures were removed from the shaker and filtered. The leachates stored in a refrigerator for chemical analyses. All measurements were done according to the Standard Methods for the Examination of Water and Wastewater. Analysis of the APS and the leachates obtained after batch experiments were initially performed using $\mathrm{pH}(\mathrm{pH} 211$ Autocalibration bench $\mathrm{pH} / \mathrm{mV}$ meter - Hanna instruments) and electrical conductivity (Conductivity meter - version Cond 315i - WTW). The metal concentrations were determined using a Thermo Jarrell-Ash ICAP-9000 ICP-AE Spectrometer.

\section{Results and discussion}

\subsection{Water treatment experiments}

\subsubsection{Batch experiments using APS}

Raw materials (FA and NC) were investigated in terms of their potential as adsorbents during the treatment of model solutions artificially polluted with selected metals. The values of $\mathrm{pH}, \mathrm{EC}$ and concentration of metal ions in the APS and those of 
the leachates obtained after treatment are summarized in Table 1. The kinetics of the neutralization reaction was investigated by monitoring the $\mathrm{pH}$ and electrical conductivity (EC).

Figure 1 illustrates the variation of solution $\mathrm{pH}$ and EC throughout the time during the batch reactions of FA and $\mathrm{NC}$ with the APS. As shown in Figure 1a, an almost constant $\mathrm{pH}$ trend was observed using NC (4.53-4.99), with no breakthrough to alkaline $\mathrm{pH}$. However, FA caused $\mathrm{pH}$ increasing rapidly from 3.82 to 10.76 within the first 5 minutes. This cannot be explained as the result of the free $\mathrm{CaO}$ present in $\mathrm{FA}$, taking into account that FA is a class $\mathrm{F}\left[\left(\mathrm{SiO}_{2}+\mathrm{Al}_{2} \mathrm{O}_{3}+\mathrm{Fe}_{2} \mathrm{O}_{3}\right) \geq\right.$ $70 \%$ ] with a very low content of $\mathrm{CaO}$. Therefore, during the equilibration of FA with the aqueous media, the neutralization of the APS's $\mathrm{pH}$ can be attributed to the fact that the FA surface is spanned by charged $\mathrm{OH}$-silanol groups and hydrolysis of these surface-SiOH sites (Hendricks, 2005). The reaction rate decreases as equilibrium is approached, with an apparent equilibrium $\mathrm{pH}$ of 11.80 being reached within 1 hour. The lack of buffering capacity for the APS can be attributed to the very low concentration of $\mathrm{Fe}^{3+} / \mathrm{Fe}^{2+}, \mathrm{Al}^{3+}, \mathrm{Mn}$ (Uhlmann et al., 2004). The $\mathrm{pH}$ had a very important role in the adsorption/removal of the contaminants probably due to the charge developed on the surfaces of the adsorbent as the $\mathrm{pH}$ increase. The EC (Figure 1b) also shows an abrupt increase from 3.76 to $7.94 \mathrm{mS} / \mathrm{cm}$ within the first 5 minutes, which becomes stable after 1 hour of contact time, when FA was used as sorbent. However, NC shows a very constant behaviour.

Table 1. pH, EC and metal ion concentration data in the raw and treated APS.

\begin{tabular}{|c|c|c|c|c|c|c|c|c|}
\hline \multirow{2}{*}{$\begin{array}{c}\text { Contact time } \\
(\min )\end{array}$} & \multirow{2}{*}{$\mathrm{pH}$} & \multirow{2}{*}{$\mathrm{E} \mathrm{C}(\mathrm{mS} / \mathrm{cm})$} & \multirow{2}{*}{$\mathrm{T}\left({ }^{\circ} \mathrm{C}\right)$} & \multicolumn{5}{|c|}{ Heavy metal concentration ( $\mathrm{ppm}$ ) } \\
\hline & & & & $\mathrm{Cu}$ & $\mathrm{Pb}$ & $\mathrm{Zn}$ & $\mathrm{Cr}$ & $\mathrm{Ni}$ \\
\hline APS & 3.82 & 3.76 & 15.5 & 8.12 & 6.35 & 3.56 & 8.32 & 6.27 \\
\hline \multicolumn{9}{|c|}{ Batch reaction of $F A$} \\
\hline 5 & 10.76 & 7.94 & 16.60 & 0.05 & 0.30 & 0.02 & 0.04 & 0.31 \\
\hline 10 & 11.2 & 9.44 & 16.80 & 0.00 & 0.00 & 0.00 & 0.10 & 0.00 \\
\hline 30 & 11.3 & 10.27 & 16.60 & 0.00 & 0.00 & 0.00 & 0.08 & 0.00 \\
\hline 45 & 11.67 & 13.45 & 16.90 & 0.00 & 0.00 & 0.00 & 0.06 & 0.00 \\
\hline 60 & 11.8 & 13.31 & 17.20 & 0.00 & 0.00 & 0.00 & 0.08 & 0.00 \\
\hline 120 & 11.67 & 15.08 & 17.40 & 0.00 & 0.00 & 0.00 & 0.10 & 0.00 \\
\hline 180 & 11.77 & 14.53 & 18.00 & 0.00 & 0.00 & 0.00 & 0.09 & 0.00 \\
\hline 240 & 11.71 & 14.18 & 18.50 & 0.00 & 0.00 & 0.00 & 0.08 & 0.00 \\
\hline 300 & 11.9 & 15.26 & 19.10 & 0.00 & 0.00 & 0.00 & 0.10 & 0.00 \\
\hline \multicolumn{9}{|c|}{ Batch reaction of NC } \\
\hline 5 & 4.53 & 4.32 & 16.4 & 1.76 & 1.85 & 2.32 & 0.01 & 1.81 \\
\hline 10 & 4.99 & 4.63 & 16.3 & 1.29 & 1.63 & 2.17 & 0.01 & 1.57 \\
\hline 30 & 4.93 & 4.14 & 16.9 & 1.69 & 1.70 & 2.07 & 0.02 & 1.68 \\
\hline 45 & 4.85 & 4.26 & 16.9 & 1.42 & 1.87 & 2.27 & 0.02 & 1.82 \\
\hline 60 & 4.75 & 4.3 & 17.2 & 1.33 & 1.70 & 2.14 & 0.01 & 1.60 \\
\hline 120 & 4.68 & 4.16 & 18.1 & 1.35 & 1.49 & 1.86 & 0.03 & 1.45 \\
\hline 180 & 4.82 & 4.25 & 18.4 & 1.40 & 1.61 & 1.87 & 0.03 & 1.54 \\
\hline 240 & 4.92 & 4.15 & 18.8 & 1.20 & 1.53 & 1.85 & 0.04 & 1.46 \\
\hline 300 & 4.84 & 4.08 & 16.6 & 1.24 & 1.51 & 1.83 & 0.04 & 1.43 \\
\hline
\end{tabular}

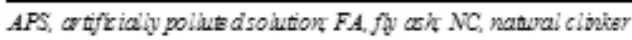



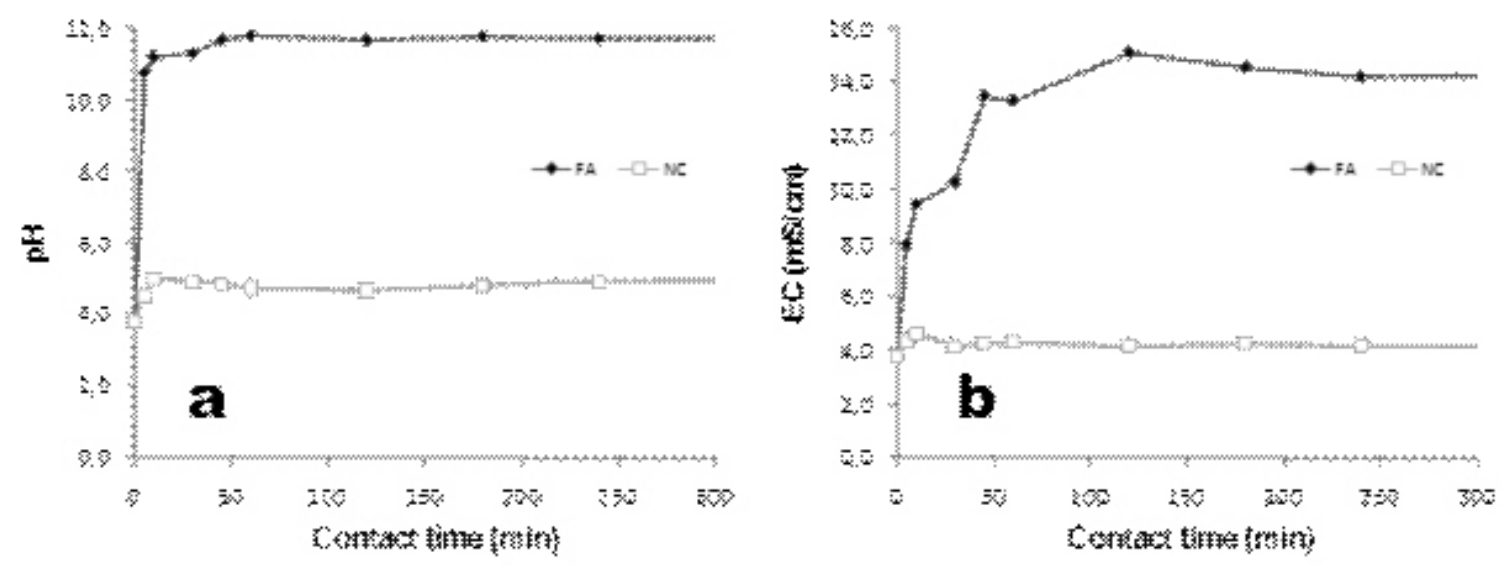

Figure 1.pH (a) and EC (b) variation as a function of time in APS treated with coal by-products. Starting reaction conditions: $p H=3.82, E C=3.76 \mathrm{mS} / \mathrm{cm}$, sorbent dosage $=0.5 \mathrm{~g}$, and volume of $A P S=20 \mathrm{ml}$.

The kinetics of the metal ions adsorption was also studied over 24 hours. Metal removal trends as a function of contact time after batch reaction are illustrated in Figure 2. Results indicate that FA produced a steep decrease in $\mathrm{Cu}, \mathrm{Pb}, \mathrm{Zn}$ and $\mathrm{Ni}$ concentration within the first 5 minutes, reaching very low residual concentrations. However, after 10 minutes plateau values were reached for the rest of the time intervals, indicating a complete removal. Cr shows an abrupt increase in concentration from 5 to 10 minutes due to the dominant occurrence of $\mathrm{Cr}(\mathrm{OH})_{4^{-}}$at $\mathrm{pH}>10$, which increases the solubility of $\mathrm{Cr}^{3+}$. It decreases from 10 to 45 minutes and increase again from 45 to 120 minutes. Cr tends to stabilize at values between 0.08 and $0.11 \mathrm{ppm}$. With the exception of $\mathrm{Cr}$, the heavy metal exchange character is irreversible. In general, NC produced inconsistency in the variation of heavy metal concentration, which is shown by the fluctuations observed during the batch experiments, although a lower sorption of $\mathrm{Zn}, \mathrm{Pb}, \mathrm{Ni}$ and $\mathrm{Cu}$ was observed which can be attributed to the higher selectivity to $\mathrm{Cr}$ by NC. The poor ion-uptake capacity of NC can be explained by the competition between hydronium ions and metal ions for exchange sites (Hendricks, 2005).

The removal efficiency of metal ions by FA and $\mathrm{NC}$ produced the following ranges: $\mathrm{Cu}$ from 93 (NC) to $100 \%$ (FA); $\mathrm{Pb}$ from 96 (NC) to $100 \%$
(FA); Zn from 50 (NC) to $100 \%$ (FA); Ni from 78 (NC) to $100 \%$ (FA); Cr $100 \%$ (FA and NC). All metal ions were rapidly removed by FA within 30 minutes with $99-100 \%$ of the metal removal achieved in the first 5 minutes. However, NC produced lower metal removal (40-84\%), except for $\mathrm{Cr}(100 \%)$. Therefore, the competition for sorbent adsorption sites in the presence of $\mathrm{Cr}$ produced a decrease in the uptake of the other metal ions. No significant adsorption was observed after 60 minutes of reaction.

The immobilization of heavy metals from aqueous media is a complex process, which consists of ion exchange and adsorption and is likely to be accompanied by precipitation of metal hydroxide complexes on active sites of the particle surface (Peric et al., 2004). The addition of an alkaline material such as FA to the APS increased the $\mathrm{pH}>9$ and most of metal ions could be hydrolyzed and precipitated as suggested by Evangelou and Zhang (1995). The efficiency of the tested FA with respect to metal retention and/or metal concentration control during its application for the treatment of metal-bearing aqueous media is governed by parameters like contact time, $\mathrm{pH}$, temperature and FA origin (Hequet et al., 2000). On the other hand, mechanisms of interactions, such as precipitation and adsorption, between a specific metal and this coal-by product are strongly influenced by $\mathrm{pH}$. 

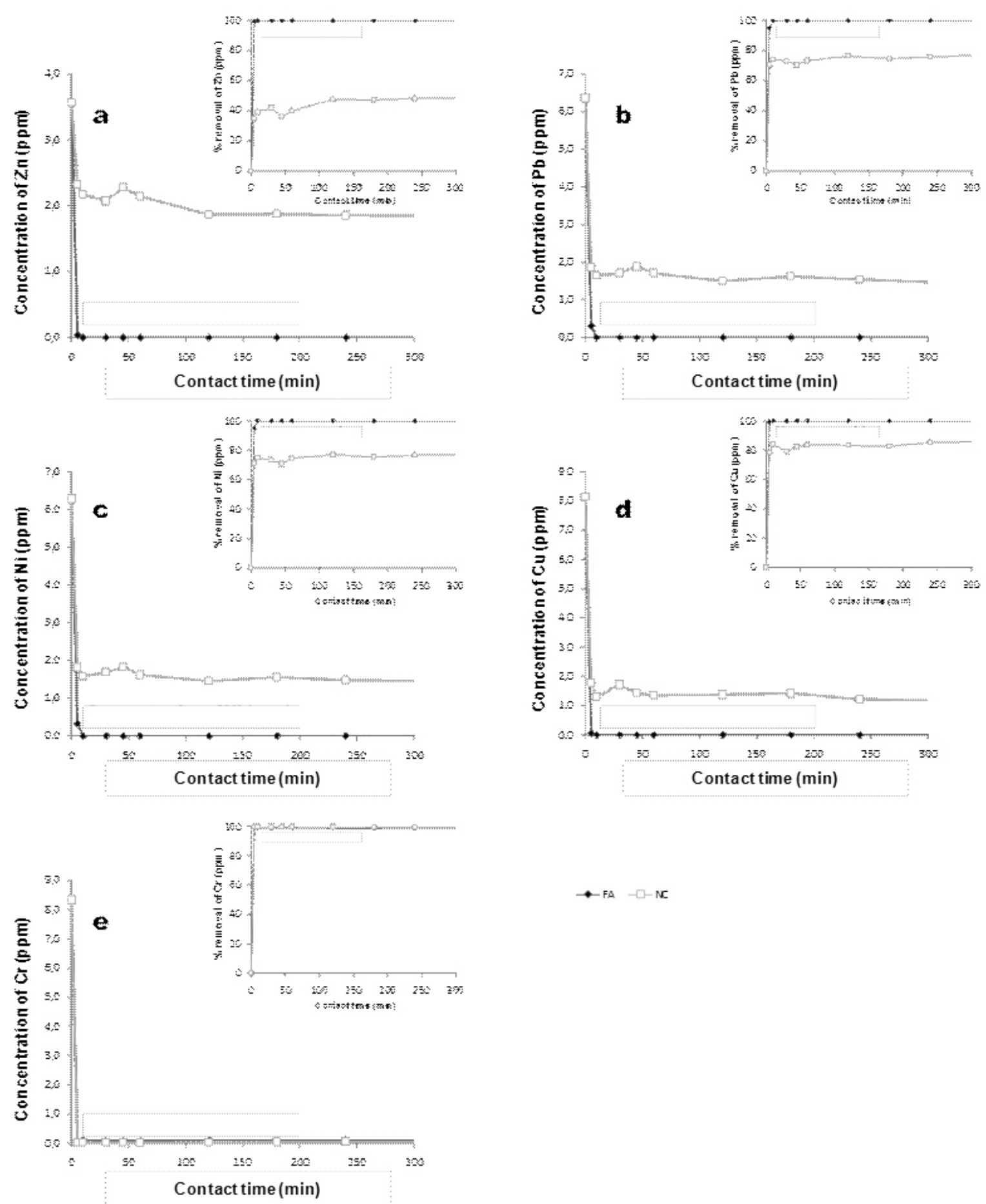

Figure 2. Heavy metal concentration variation as a function of time during the adsorption batch experiments with the following starting reaction conditions: $\mathrm{pH}=3.82, E C=3.76 \mathrm{mS} / \mathrm{cm}$, sorbent dosage $=0.5 \mathrm{~g}$, and volume of APS $=20$ 
Table 2. $p H, E C$ and concentration data of metal ions in the raw and treated AMD.

\begin{tabular}{|c|c|c|c|c|c|c|c|c|c|c|}
\hline \multirow{2}{*}{$\begin{array}{c}\text { Contact time } \\
(\min )\end{array}$} & \multirow{2}{*}{$\mathrm{pH}$} & \multirow{2}{*}{$\mathrm{E} \mathrm{C}(\mathrm{mS} / \mathrm{cm})$} & \multirow{2}{*}{$\mathrm{T}\left({ }^{\circ} \mathrm{C}\right)$} & \multicolumn{7}{|c|}{ Heavy metal concentration (ppm) } \\
\hline & & & & $\mathrm{Cu}$ & $\mathrm{Pb}$ & $\mathrm{Zn}$ & $\mathrm{Cr}$ & $\mathrm{Ni}$ & As & $\mathrm{Fe}$ \\
\hline AMD & 1.96 & 3.77 & 16.00 & 31.90 & 2.10 & 73.83 & 0.05 & 0.02 & 4.81 & 1355.33 \\
\hline \multicolumn{11}{|l|}{ Batch reaction } \\
\hline 5 & 2.54 & 6.47 & 20.60 & 56.64 & 1.35 & 52.12 & 0.36 & 0.12 & 3.03 & 913.57 \\
\hline 10 & 2.56 & 6.93 & 20.60 & 53.73 & 1.23 & 50.52 & 0.31 & 0.08 & 2.92 & 901.30 \\
\hline 30 & 2.51 & 5.85 & 20.90 & 53.65 & 1.30 & 51.35 & 0.39 & 0.12 & 3.01 & 904.80 \\
\hline 45 & 2.13 & 5.73 & 20.80 & 66.58 & 1.96 & 62.85 & 0.70 & 0.51 & 3.59 & 1068.04 \\
\hline 60 & 2.46 & 5.48 & 21.50 & 55.73 & 1.60 & 52.41 & 0.58 & 0.42 & 3.01 & 906.62 \\
\hline 120 & 2.38 & 5.01 & 21.20 & 55.28 & 1.41 & 51.86 & 0.46 & 0.24 & 3.00 & 914.04 \\
\hline 180 & 2.38 & 5.00 & 21.70 & 56.62 & 1.58 & 53.49 & 0.55 & 0.38 & 3.03 & 941.46 \\
\hline 240 & 2.34 & 5.13 & 22.70 & 55.17 & 1.46 & 53.23 & 0.54 & 0.32 & 3.13 & 916.34 \\
\hline 1440 & 2.66 & 5.04 & 20.90 & 79.07 & 1.96 & 72.35 & 0.79 & 0.52 & 4.13 & 1156.62 \\
\hline \multicolumn{11}{|l|}{ Batch reaction } \\
\hline 5 & 2.42 & 8.80 & 20.60 & 48.55 & 1.14 & 48.26 & 0.05 & 0.03 & 2.25 & 853.62 \\
\hline 10 & 3.04 & 8.91 & 20.50 & 49.74 & 1.17 & 49.41 & 0.05 & 0.03 & 2.31 & 891.74 \\
\hline 30 & 2.64 & 8.87 & 20.70 & 48.64 & 1.15 & 49.11 & 0.05 & 0.04 & 2.30 & 864.14 \\
\hline 45 & 2.00 & 8.93 & 21.00 & 49.49 & 1.23 & 49.29 & 0.04 & 0.07 & 2.33 & 882.10 \\
\hline 60 & 1.92 & 8.82 & 21.20 & 49.37 & 1.68 & 49.26 & 0.23 & 0.51 & 2.29 & 877.85 \\
\hline 120 & 1.92 & 8.76 & 21.40 & 48.76 & 1.22 & 49.53 & 0.042 & 0.05 & 2.31 & 883.55 \\
\hline 180 & 1.92 & 8.93 & 21.50 & 50.30 & 1.26 & 50.72 & 0.06 & 0.09 & 2.38 & 909.89 \\
\hline 240 & 1.86 & 8.95 & 22.40 & 53.79 & 1.29 & 52.88 & 0.03 & 0.15 & 2.62 & 890.04 \\
\hline 1440 & 1.86 & 10.38 & 20.50 & 76.41 & 2.40 & 71.04 & 0.39 & 0.85 & 3.61 & 1168.67 \\
\hline
\end{tabular}

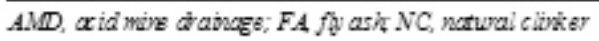

\subsubsection{Batch experiments using AMD}

In the following section we discuss the results of adsorption experiments performed with FA and $\mathrm{NC}$ to treat AMD. Table 2 summarizes the values of the $\mathrm{pH}, \mathrm{EC}$ and concentration of metal ions in the untreated AMD and those of the leachates obtained after treatment. Here, we consider very important to examined the As and Fe removal, taking into account that As is known to be a hazardous contaminant in drinking water that causes different diseases, and Fe that generally not produce polluted effluents in terms of metal toxicity, but can be highly ferruginous and visibly unsightly as $\mathrm{Fe}$ oxyhydroxide precipitates are deposited as coating effectively smothers the environment and prevents life from flourishing (McGinness, 1999). Figure 3 shows the $\mathrm{pH}$ and EC trends for the neutralization reactions between the
AMD and the raw materials. A pH increase from 1.96 to 2.54 (FA) and 2.42 (NC) was observed within 5 minutes. The reaction rates decrease as equilibrium is approached. The $\mathrm{pH}$ was stabilized within 1 hour when the raw materials were reacted with AMD. The final $\mathrm{pH}$ ranges from 1.86 to 2.66. In this case, there was also not observed breakthrough to alkaline $\mathrm{pH}$, which indicates that contact time did not affect the alkalinity using a dosage of $0.25 \mathrm{~g}$. However, Ríos et al. (2008) have determined that using a higher sorbent dose a strong change in $\mathrm{pH}$ was observed. EC ranges from 5.00-6.93 (FA) to $8.76-10.38$ (NC) $\mathrm{mS} / \mathrm{cm}$ were obtained. We have carried out additional experiments increasing the sorbent dose $(1 \mathrm{~g})$, resulting an increase of $\mathrm{pH}$ in the batch experiments after 24 hours of contact time, with $\mathrm{pH}$ values between 4.20 and 9.43, except when NC was used $(\mathrm{pH} \geq 1.85)$. 

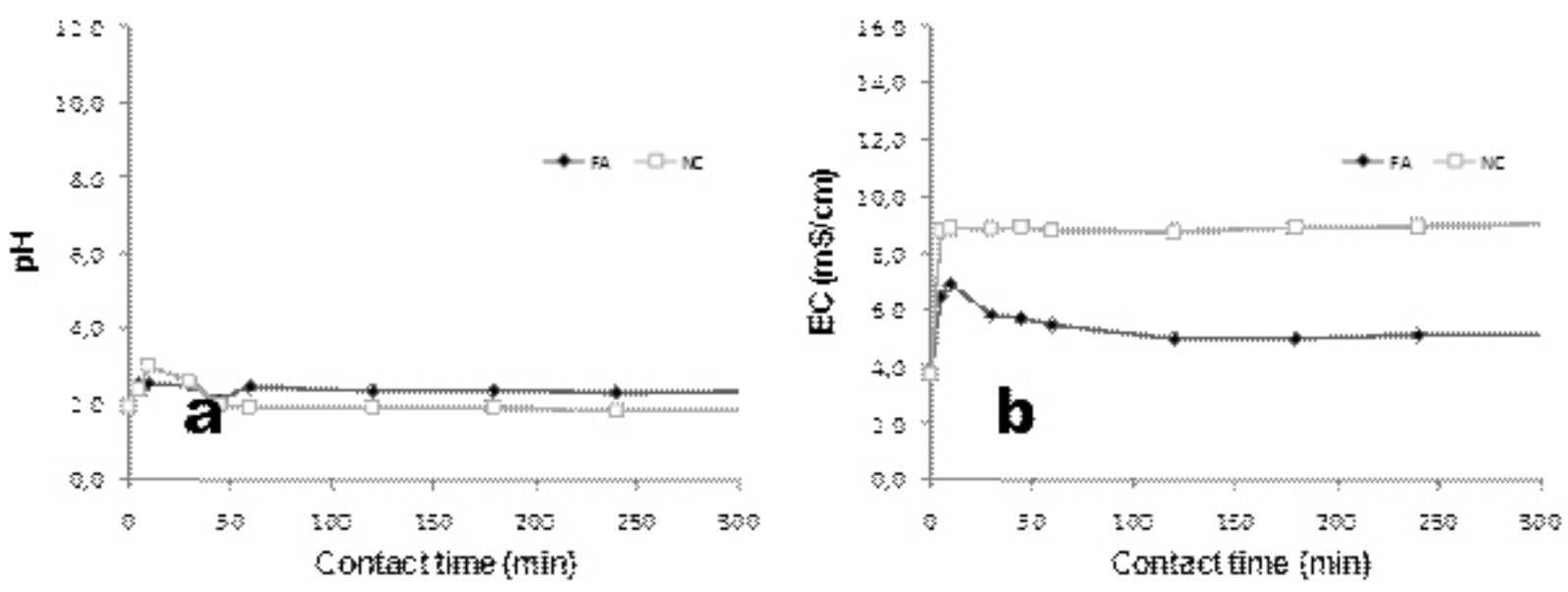

Figure 3. $p H$ (a) and EC (b) variation as a function of time in AMD treated with coal by-products. Starting reaction conditions: $p H=1.96, E C=3.77 \mathrm{mS} / \mathrm{cm}$, sorbent dosage $=0.25 \mathrm{~g}$, and volume of $A M D=20 \mathrm{ml}$.

Metal removal trends as a function of contact time after batch reaction (results not shown) reveal that when FA or $\mathrm{NC}$ were added to the AMD a sudden drop in $\mathrm{Pb}, \mathrm{Zn}, \mathrm{Fe}$ and $\mathrm{As}$ and a sudden increase in $\mathrm{Cu}$, with a small increase in $\mathrm{Ni}$ was observed after 5 minutes. An abrupt increase in $\mathrm{Cu}, \mathrm{Pb}, \mathrm{Zn}, \mathrm{Ni}, \mathrm{Fe}$ and As was observed after 45 minutes and then decrease to stabilize, when FA was used. A similar behaviour was observed using $\mathrm{NC}$ as sorbent, although just for $\mathrm{Pb}$ and $\mathrm{Ni}$ and after 1 hour. The addition of FA and NC produced an abrupt decrease in those elements after 45 minutes, except $\mathrm{Cr}$ (for $\mathrm{FA}$ ), $\mathrm{Ni}$ and $\mathrm{Cu}$, which show a strong reversal character. In general, $\mathrm{Cr}$ shows a constant behaviour and very low concentrations, except when FA was used as a consequence of the dominant occurrence of chromium species in acidic conditions, which increases the solubility of $\mathrm{Cr}^{3+}$ in FA). The \% of removal efficiency show that the use of raw materials produced the following ranges $\mathrm{Pb}$ from $42-46$ to $94-96 \% ; \mathrm{Zn}$ from $32-33$ to $40-42 \%$; As from $39-53$ to 99 $100 \%$; $\mathrm{Fe}$ from $33-37$ to $100 \%$. $\mathrm{Cu}, \mathrm{Cr}$ and $\mathrm{Ni}$ produced negative $\%$ values, which indicate the poor removal efficiency.

\subsection{Sorption of metal ions from aqueous solutions on the sorbents}

It has been more than a hundred years since Lagergren suggested the first-order equation for describing liquidsolid adsorption systems in 1898, and it is still widely applied today. Lagergren's kinetics equation may have been the first one in describing the adsorption of liquid-solid systems based on solid capacity (Ho, 2004) and has been most widely used for the adsorption of an adsorbate from an aqueous solution. In order to distinguish kinetics equation based on adsorption capacity of solid from concentration solution, Lagergren's first-order rate equation has been called by Ho and McKay (1999) as pseudo-first order.

The sorption process considered here refers to a sorbent (FA or NC) and a polluted aqueous media (APS or AMD) containing dissolved metal ions to be sorbed. There is a strong affinity of the sorbent for the metal ions, which are attracted into the sorbent and bound there by different mechanisms. Ríos et al. (2008) consider that the main mechanism for metal uptake is precipitation of metal complexes on the surface of the sorbent and not sorption. The metal ion uptake by the sorbent is evaluated on how much metal ion can be attracted and retained in an immobilized form and can be determined by the equation (1):

$$
q_{e}=\left(C_{o}-C_{f}\right) V / m
$$


$\mathrm{C}_{o}$ is the initial concentration in the untreated solution and $\mathrm{C}_{t}$ is the concentration of metal ion in solution after adsorption at a specific time $(t), V$ is the volume of the metal-bearing solution contacted with the sorbent $(\mathrm{L})$ and $\mathrm{m}$ is the mass of the sorbent added $(\mathrm{g})$.

The removal efficiency of metal ions by the adsorbent was calculated using the expression:

$$
\% \text { Removal Efficiency }=100(\mathrm{Co}-\mathrm{Ct}) / \mathrm{Co}
$$

The kinetics of heavy metal adsorption on FA and $\mathrm{NC}$ were modelled using the pseudo-first order kinetic equation suggested by Lagergren (1898), which can be written as

$$
\frac{d q_{t}}{d t}=k_{1}\left(q_{e}-q_{t}\right)
$$

The term $k_{l}\left(\mathrm{~min}^{-1}\right)$ is the first order adsorption rate constant, $q_{e}$ is the amount of metal adsorbed at equilibrium and $q_{t}$ is the amount adsorbed at a specific time ( $\mathrm{t}$ ). Integrating equation (2) from $q_{t} \geq$ 0 at $\mathrm{t} \geq 0$, gives

$$
\begin{gathered}
\ln \left(\frac{q_{e}-q_{t}}{q_{e}}\right)=-k_{1} t \\
\text { Or } \\
q_{t}=q_{e}\left(1-e^{-k_{1} t}\right)
\end{gathered}
$$

(Non-linear form)

The first order rate equation applied throughout all the contact times. The values of $q_{t}$ were nonlinearly correlated with $t$. The plots of $q_{t}$ against $t$ for the metal ions using the raw sorbents are illustrated on Figures 4 and 5.
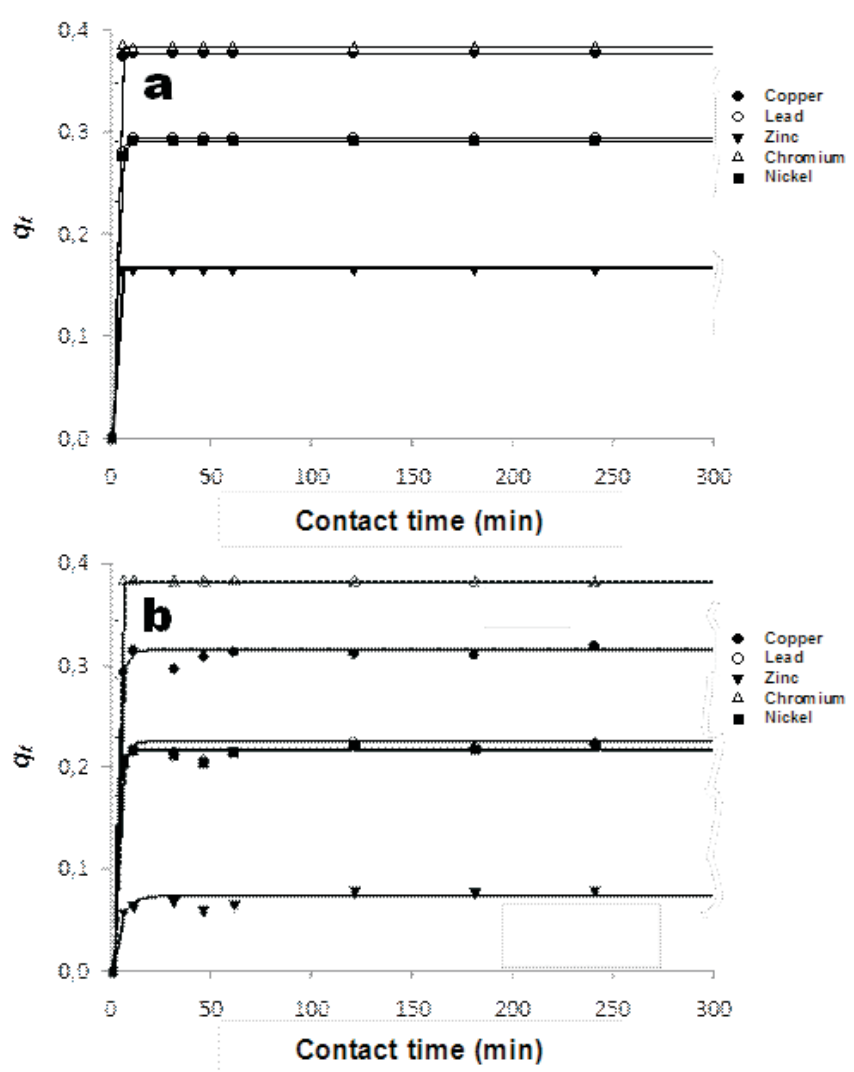

Figure 4. Lagergren non linear plots (first order) at room temperature for metal ion adsorption on (a) FA and (b) NC from APS. 

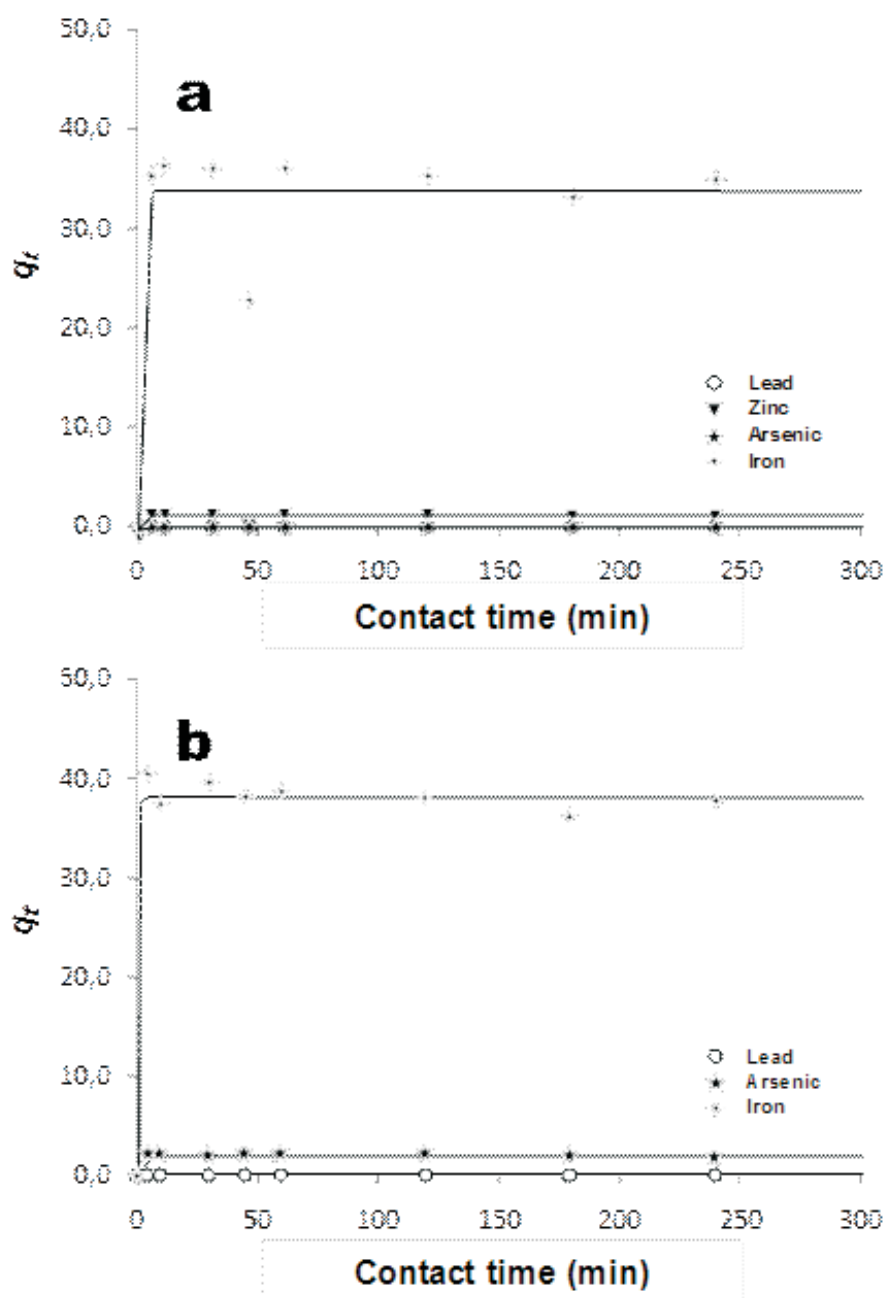

Figure 5. Lagergren non linear plots (first order) at room temperature for the metal ion adsorption on (a) FA and (b) NC from AMD.

The conformity between experimental data and the model predicted values was expressed by the correlation coefficients $\left(\mathrm{R}^{2}\right)$. $\mathrm{R}^{2}$ values for the pseudo-first order equation are shown on Tables 3 and 4 , with values close or equal to 1 for treated APSs, whereas using AMDs, values ranging from 0.25 to 0.99 were obtained using the raw materials. The treatment of AMD with the raw materials produced low $\mathrm{R}^{2}$ values, which indicates a poor correlation. In general, the correlation coefficients for these plots are excellent (in most of the cases $>0.99$ ), indicating that the model successfully describes the kinetics of the adsorption. The calculated slopes and intercepts from the plots were used to determine the rate constant $\mathrm{k}_{1}$ and theoretical equilibrium capacity $\left(q_{e}\right)$ and their values are depicted on Tables 3 and 4 . The experimental $q_{e}$ values were compared to $q_{e}$ values determined by pseudo-first order rate kinetic model. The $q_{e}$ values exhibit excellent agreement with the experimental $q_{e}$ values.

\section{Conclusions}

A cost effective treatment procedure was proposed for the removal of heavy metals from 
Table 3. Pseudo-first order kinetic parameters for the metal ion adsorption on the raw materials using APS.

\begin{tabular}{|c|c|c|c|c|c|}
\hline Parameters & $\mathrm{Pb}$ & $\mathrm{Zn}$ & $\mathrm{As}$ & $\mathrm{Fe}$ & $\mathrm{Cr}$ \\
\hline \multicolumn{6}{|c|}{ Fly ash } \\
\hline$k_{l}\left(\min ^{-1}\right)$ & 1.020 & 0.610 & 0.990 & 11.200 & 0.600 \\
\hline$q_{s}$ (experimental) & 0.345 & 0.254 & 0.143 & 0.329 & 0.251 \\
\hline$q=$ (theoretical) & 0.324 & 0.254 & 0.143 & 0.329 & 0.251 \\
\hline$R^{2}$ & 1.000 & 1.000 & 1.000 & 0.999 & 1.000 \\
\hline \multicolumn{6}{|c|}{ Natwal clinker } \\
\hline$k_{l}\left(\min ^{-1}\right)$ & 0.532 & 0.496 & 0.287 & 743.500 & 0.588 \\
\hline$q_{c}$ (experimental) & 0.301 & 0.245 & 0.071 & 0.332 & 0.198 \\
\hline$q=$ (theoretical) & 0.274 & 0.195 & 0.063 & 0.332 & 0.188 \\
\hline$R^{2}$ & 0.984 & 0.920 & 0.913 & 1.000 & 0.993 \\
\hline
\end{tabular}

Table 4. Pseudo-first order kinetic parameters for the metal ion adsorption on the raw materials using $A M D$.

\begin{tabular}{|c|c|c|c|c|c|}
\hline Parameters & $\mathrm{Pb}$ & $\mathrm{Zn}$ & $\mathrm{As}$ & $\mathrm{Fe}$ & $\mathrm{Cr}_{\mathrm{r}}$ \\
\hline \multicolumn{6}{|c|}{ Fly ash } \\
\hline$k_{l}\left(\min ^{-1}\right)$ & 231.510 & 26.650 & 9.644 & 49.122 .150 & $\ldots$ \\
\hline$q_{\mathrm{s}}$ (experimenta) & 0.050 & 1.650 & 0.135 & 35.120 & - \\
\hline$q=$ (theoretical) & 0.045 & 1.460 & 0.130 & 33.790 & - \\
\hline$R^{2}$ & 0.336 & 0.415 & 0.645 & 0.880 & $\ldots$ \\
\hline \multicolumn{6}{|c|}{ Natwal clinker } \\
\hline$k_{l}\left(\min ^{-1}\right)$ & 6.410 & 241.560 & 9.644 & 20.110 & -- \\
\hline$q_{c}$ (experimental) & 0.060 & 1.850 & 0.180 & 37.220 & - \\
\hline$q=$ (theoretical) & 0.570 & 1.730 & 0.130 & 37.900 & $\ldots$ \\
\hline$R^{2}$ & 0.249 & 0.505 & 0.647 & 0.990 & $\ldots$ \\
\hline
\end{tabular}

APS and AMD through adsorption on FA and NC. Removal increased with increasing contact time, adsorbent amount and solution $\mathrm{pH}$. The Lagergren's pseudo-first-order equation shows an excellent fit as indicated by the correlation coefficient $\left(\mathrm{R}^{2}\right)$. Data from this study reveal that metal cations from aqueous solution can be adsorbed successfully in significant amounts by the used adsorbents. The results of this investigation both contribute to the mitigation of environmental problems and turns a coal byproducts, such as FA and NC, into attractive and useful products. However, further research studies on the use of these industrial wastes as starting materials in the synthesis of highly crystalline zeolitic materials under well-optimized conditions and to estimate if these materials are potentially useful for wastewater treatment or not to establish the factors affecting their application and to evaluate the social and environmental effects of their proposed utilization approach.

\section{Acknowledgments}

C.A. Ríos acknowledges the Programme AlBan, the European Union Programme of High Level Scholarships for Latin America (scholarship no. E05D060429CO), and the Universidad Industrial de Santander (remunerated commission). The authors acknowledge the School of Applied 
Sciences at the University of Wolverhampton for the use of research facilities. We are also thankful to Dr. Wilson Gitari and Ms. Leslie Petrik from the Environmental and Nano sciences group, University of the Western Cape, South Africa, for their assistance with the design and preparation of adsorption experimental tests.

\section{References}

Chartrand, M.M.G., \& Bunce, N.J. (2003). Electrochemical remediation of acid mine drainage. Journal of Applied Electrochemistry 33 (3-4), 259-264.

Cosca, M., Essene, E., Geissman, J., Simmons, W., \& Coates, D. (1989). Pyrometamorphic rocks associated with naturally burned coal beds, Powder River Basin. Wyoming. American Mineralogist 74 (1-2), 85-100.

De Boer, C., Dekkers, M., \& Van Hoof, T. (2001). Rock-magnetic properties of TRM carrying baked and molten rocks straddling burnt coal seams. Physics of the Earth and Planetary Interiors 126 (1), 93-108.

Dubrovsky, N.M., Cherry, J.A., Reardon, E.J., \& Vivyurka. A.J. (1985). Geochemical evolution of inactive pyritic tailings in Elliott Lake uranium district. Canadian Geotechnical Journal 22 (1), 110-128.

Evangelou, V.P., \& Zhang, Y.L. (1995). A review: Pyrite oxidation mechanisms and acid mine drainage prevention. Critical Reviews in Environmental Science and Technology 25 (2), 141-199.

Feasby, D.G., Blanchette, M., Tremblay, G., \& Sirois, L.L. (1991). The mine environment neutral drainage program. In: Proceedings of the 2 nd International Conference on the Abatement of Acidic Drainage, Montreal, PQ. 1, 1-26.

Feng, D., Aldrich, C., \& Tan, H. (2000). Treatment of acid mine water by use of heavy metal precipitation and ion exchange. Minerals Engineering 13 (6), 623-642.
Gibert, O., de Pablo, J., Cortina, J.L., \& Ayora, C. (2005). Sorption studies of $\mathrm{Zn}$ (II) and $\mathrm{Cu}$ (II) onto vegetal compost used on reactive mixtures for in situ treatment of acid mine drainage. Water Research 39 (13), 2827-2838.

Hendricks, N.R. (2005). The application of high capacity ion exchange adsorbent material synthesized from fly ash and acid mine drainage, for the removal of heavy and trace metals from secondary co-disposed process waters, Master's thesis, University of the Western Cape.

Hequet, V., Ricou, P., Lecuyer, I., \& LeCloirec, P. (2000). Removal of $\mathrm{Cu}^{2+}$ and $\mathrm{Zn}^{2+}$ from aqueous solutions by sorption onto mixed fly ash. Fuel 80 (6), 851-856.

Ho, Y.S. (2004). Citation review of Lagergren kinetic rate equation on adsorption reactions. Scientometrics 59(1), 171-177.

Kalin, M., Fyson, A., \& Wheeler, W.N. (2006). The chemistry of conventional and alternative treatment systems for the neutralization of acid mine drainage. Science of the Total Environment 366(2-3), 395-408.

McGinness, S. (1999). Treatment of acid mine drainage. Research Paper 99/10. House of Common Library. Available on http://www.parliament.uk/documents/commons/1 ib/research/rp99/rp99-010.pdf

Mohan, D., \& Chander, S. (2000). Single component and multi-component adsorption of metal ions by activated carbons. Colloids and Surfaces A: Physicochemical and Engineering Aspects 177 (2-3), 183-196.

Peric, J., Trigo, M., \& Medvidović, N.V. (2004). Removal of zinc, copper and lead by natural zeolite - a comparison of adsorption isotherms. Water Research 38 (7), 1893-1899.

Rios, C.A., Williams, C.D., \& Roberts, C.L. (2008). Removal of heavy metals from acid mine drainage (AMD) using coal fly ash, natural clinker and synthetic zeolites. Journal of Hazardous Materials 156(1-3), 23-35. 
Uhlmann, W., Buttcher, H., Totsche, O., \& Steinberg, C.E.W. (2004). Buffering of acidic mine lakes: The relevance of surface exchange and solid bound sulphate. Mine Water and the Environment 23(1), 20-27.

Webster, J.G., Swedlund, P.J., \& Webster, K.S. (1998). Trace metal adsorption onto an acid mine drainage iron (III) oxy hydroxy sulphate. Environmental Science and Technology 32 (10), 1361-1368.

Wei, X., Viadero Jr., R.C., \& Buzby, K.M. (2005). Recovery of iron and aluminium from acid mine drainage by selective precipitation. Environmental Engineering Science 22 (6), 745-755.

Zhang, X., Kroonenberg, S.B., \& De Boer, C. (2004). Dating of coal fires in Xinjiang, north-west China. Terra Nova 16(2), 68-74. 